\title{
SISTEM INFORMASI PENGELOLAAN DATA LAPORAN HASIL PRODUKSI BERBASIS WEBSITE PADA PT. NIKONA GRAHA TANGERANG
}

\author{
Giandari Maulani ${ }^{1}$ \\ Kartika Chandra Buana Sejati ${ }^{2}$ \\ Zahrotul Hayati ${ }^{3}$ \\ Dosen Tetap STMIK Raharja ${ }^{1}$,Mahasiswa STMIK Raharja Jurusan Sistem Informasi ${ }^{3}$ \\ Jl. Jendral Sudirman No 40, Modernland Tangerang ${ }^{1,2,3}$ \\ email: giandari@raharja.info,chandrabuana@raharja.info,zahrotulhayati@raharja.info
}

\begin{abstract}
ABSTRAK
Perkembangan teknologi dan informasi di zaman era globalisasi saat ini berkembang sangat pesat. Selain sebagai salah satu media komunikasi dan informasi, adanya teknologi dan informasi juga membantu manusia dalam menyelesaikan segala pekerjaan. Komputer mempunyai kegunaan dalam mendeteksi kesalahan data yang di olah dan dapat melakukan pekerjaan di luar kemampuan manusia sehingga keterlambatan suatu pekerjaan dapat dihindari. Salah satunya pada PT.Nikona Graha Tangerang seringkali menghadapi permasalahan pada pengelolaan data laporan hasil produksi. Dalam pengelolaan data laporan hasil produksi yang dilakukan oleh bagian produksi masih memiliki beberapa kekurangan yaitu proses pencatatan laporan hasil produksi yang dilakukan oleh bagian produksi masih menggunakan kertas dan tidak bisa melakukan penginputan laporan hasil produksi di hari yang sama karena laporan hasil produksi dicatat di formulir hasil produksi menggunakan kertas sehingga membutuhkan waktu yang lama dalam mengolah data dan penyimpanan data-datanya masih kurang aman dan kurang tertata dengan baik karena tidak adanya tempat penyimpanan data yang baik seperti kertas laporan hasil produksi bertumpuk-tumpuk diatas meja sehingga laporan hasil produksi bisa hilang dan bisa tercampur dengan laporan hasil produksi yang sudah di input. Berdasarkan masalah di atas maka penulis mengusulkan membuat aplikasi pengelolaan data laporan hasil produksi yang mudah dioperasikan dengan cepat, membuat aplikasi yang mudah di akses oleh bagian produksi dan mempunyai tempat penyimpanan data yang aman sehingga data-data yang ada tidak mudah hilang dan juga penyimpanan data menjadi lebih terintegrasi.
\end{abstract}

Kata Kunci : laporan hasil produksi, pengelolaan data.

\section{ABSTRACT}

Development of technology and information in the age of globalization is currently growing very rapidly. Apart from being a medium of communication and information, the information technology and also help people in completing all the work. Computers have utility in detecting errors in the data though and can do the job beyond human ability to delay a job can be avoided. One of them at Graha PT.Nikona Tangerang often face problems in data management reporting production results. In the data management reports on the production done by the production still has some shortcomings, namely the process of recording reports of production carried out by the production department still use paper and can not do inputting reports production results on the same day as reports production results recorded in the form of production using paper so it takes a long time in processing the data and storing the data is still less secure and less well because of the lack 
of a good data storage such as paper reports production results in piles on the table so that the report output could be lost and can be mixed to report the results of which are already in production inputs. Based on the above problems, the authors propose to make application data management reports production results are easy to operate quickly, making applications easily accessed by the production department and has a secure data storage so that data that is not easily lost and data storage into more integrated.

Keywords: report production, data management.

\section{PENDAHULUAN}

PT. Nikona Graha Tangerang merupakan perusahaan yang bergerak di bidang Metal Komponen (Otomotif Park) untuk kendaraan bermotor. PT Nikona Graha Tangerang mempunyai jenis barang yang berbeda-beda. Di lain pihak, pengembangan sumber daya manusia akan tetap menjadi perhatian bagi pihak PT Nikona Graha Tangerang, karena PT Nikona Graha Tangerang percaya bahwa mutu sumber daya manusia yang tinggi akan menghasilkan kreatifitas dan inovasi dalam menghasilkan jenis barang seperti Metal Stamping dan Karet, Bar Main Step K-15.A, Cutting Inner dan Outter, Packing Inner dan Outter, dan Turret Inner dan Outter. menyediakan produk yang berkualitas dan selalu mengutamakan kepuasan pelanggan dengan memberikan pelayanan yang baik.

Pada PT Nikona Graha Tangerang yang dilakukan oleh bagian produksi masih memiliki beberapa kekurangan diantaranya : proses pencatatan laporan hasil produksi yang dilakukan oleh bagian produksi masih menggunakan kertas dan tidak bisa melakukan penginputan laporan hasil produksi di hari yang sama karena laporan hasil produksi dicatat di form hasil produksi menggunakan kertas sehingga membutuhkan waktu yang lama dalam mengolah data dan penyimpanan datadatanya masih kurang aman dan kurang tertata dengan baik karena tidak adanya tempat penyimpanan data yang baik seperti kertas laporan hasil produksi bertumpuk-tumpuk diatas meja sehingga laporan hasil produksi bisa hilang dan bisa tercampur dengan laporan hasil produksi yang sudah di input.

Untuk proses pencatatan laporan hasil produksi masih menggunakan kertas mulai dari laporan hasil produksi dicatat di form hasil produksi dan data hasil produksi dibuat di Ms.Excel. Hal ini dirasakan kurang baik dalam hal penyimpanannya karena data-data laporan hasil produksi bisa dibuka dan dapat dirubah oleh orang lain, bila dilihat data laporan hasil produksi yang diolah setiap harinya cukup banyak. Ini akibat kurang maksimalnya pemanfaatan teknologi komputer, padahal dengan adanya penggunaan sistem komputerisasi dapat membantu kinerja karyawan dan juga meningkatkan produktifitas karyawan, bukan hanya dalam penyimpanan data dan memberikan informasi yang cepat dan tepat, maka dalam hal ini sangat diperlukan suatu sistem pengawasan yang baik.

\section{PERMASALAHAN}

Adapun permasalahan-permasalahan yang dihadapi oleh PT Nikona Graha Tangerang saat ini antara lain :

1) Apakah dengan sistem yang berjalan pada PT Nikona Graha Tangerang pada saat ini terutama dalam hal pengelolaan data laporan hasil produksi sudah aman dalam penyimpanan datanya?

2) Bagaimana membuat sistem pengelolaan data laporan hasil produksi di PT Nikona Graha Tangerang agar menjadi lebih baik ? 


\section{LITERATUR REVIEW}

Untuk dapat mengembangkan dan menyempurnakan penelitian ini, maka perlu dilakukan studi pustaka (literature review) sebagai salah satu penerapan metode penelitian yang akan dilakukan sebagai bahan perbandingan. Diantaranya seperti dibawah ini :

1) Penelitian yang dilakukan oleh Hana Busyrol (2010) ${ }^{[1]}$, Universitas Negeri Semarang. Penelitian yang berjudul "Aplikasi Pengolahan dan Pelaporan Data Hasil Produksi Kertas NCR di PT. Pura Barutama Unit Coating Kudus". Penelitian ini membahas mengenai PT. Pura Barutama yang masih menggunakan program Ms. Word dan Ms. Excel dalam melakukan pengolahan dan pelaporan data hasil produksi kertas NCR, sehingga perlu adanya suatu aplikasi tambahan yang dapat membantu proses tersebut menjadi lebih cepat dan praktis. Tujuannya adalah membuat model aplikasi yang tepat untuk mengolah dan melaporkan data hasil produksi. Tahapan-tahapan yang digunakan adalah tahap studi kelayakan, rencana pendahuluan, analisis sistem, perencanaan sistem dan implementasi sistem dengan langkah kerja yang sederhana serta program ini mampu mempermudah dalam pengolahan data serta mempercepat dalam pembuatan laporan.

2) Penelitian yang dilakukan oleh Felicia Soedjianto, Tanti Oktavia, James Arthur Anggawinata (2006) ${ }^{[12]}$, Universitas Kristen Petra. Penelitian yang telah dilakukan oleh mereka berjudul : "Perancangan dan Pembuatan Sistem Perencanaan Produksi (Studi Kasus Pada PT Vonita Garment)". Selama ini sistem produksi yang dilakukan berdasarkan inventori atau stok gudang, dimana produksi terus berlangsung tanpa melihat permintaan penjualan. Untuk mengatasi masalah tersebut, maka dibutuhkan suatu sistem baru untuk memperbaiki sistem yang dipakai saat ini. Sistem yang dibuat ini dapat mengetahui jumlah stok barang yang diperlukan, jumlah perkiraan permintaan penjualan, hasil peramalan dengan menggunakan metode yang memiliki nilai Mean Absolute Deviation (MAD) terkecil, hasil penjadwalan produksi tiap minggudan hasil produksi. Dalam sistem produksi modern terjadi suatu proses transformasi nilai tambah yang mengubah input bahan mentah menjadi output sebuah produk yang dapat dijual di pasar dengan harga yang kompetitif. Proses produksi yang berlangsung dalam PT Vonita Garment secara umum dapat digambarkan sebagai berikut : Pembuatan pola, yaitu pembuatan pola dari masing-masing bagian pakaian (kerah, lengan, dada, dll), PT Vonita Garment memakai sistem make to stock. Karena itu dengan adanya sistem perencanaan produksi ini dapat lebih memaksimalkan produktivitas dan efektifitas dari PT Vonita Garment.

3) Penelitian yang dilakukan oleh Riwan Tri Haryono,Siska Iriani, S.Kom $(2013)^{[4]}$, Penelitian yang telah dilakukan oleh mereka berjudul : "Perancangan Sistem Informasi Pengolahan Data Produksi Dan Penjualan Pada Pabrik Penggergajian Batu CV Bumi Indah Persada". Selama ini pengolahan data produksi dan penjualan disana masih menggunakan metode konvensional dan penyimpanannya masih tersebar belum terdokumentasi dengan baik, dimana dalam penyimpanan datanya masih menggunakan Microsoft Excel dan Microsoft Word. Dari penelitian ini diharapkan dapat mempermudah sistem pencatatan bahan baku, hasil produksi dan penjualan serta laporan produksi dan penjualan harian, 
bulanan atau pun tahunan. CV. Bumi Indah Persada sistem administrasi dan pelaporan dalam pengelolaan pabrik masih dilakukan secara manual, seperti : Kesulitan dalam melakukan pelaporan data produksi, data penjualan dan stok baku, Pencatatan bahan baku, hasil produksi dan penjualan masih tumpang tindih karena belum dilakukan pelaporan terpisah sehingga perkembangan pabrik masih sulit di analisa secara cepat, Hilang dan rusaknya dokumen dan Presentase keuntungan sulit untuk di analisa.

4) Penelitian yang dilakukan oleh Nilo Legowo $(2012)^{[8]}$, dari Universitas Binus yang berjudul "Perancangan Aplikasi Monitoring Produksi Pada Perusahaan Yang Memproduksi Acrylic". Penelitian ini bertujuan untuk mempermudah monitor proses produksi, meminimalisasi human error pada proses produksi, mengotomatisasi proses transaksi yang ada, memperjelas pembagian tugas pada monitoring produksi acrylic pada perusahaan. Kemudian metode analisis dengan mempelajari sistem yang sedang berjalan pada perusahaan serta menganalisis hasil kuesioner yang telah disebarkan. Dengan sistem monitoring produksi yang dirancang untuk perusahaan ini, proses transaksi dapat berjalan secara sistematis. Selain itu, setiap proses produksi mulai dari project order, sample order, sales order, material release, production, assemblydan delivery order dapat dipantau dengan cepat sehingga laporan kegiatan proses produksi dapat dibuat lebih sistematis dan jelas.

5) Penelitian yang dilakukan oleh Femin Khristiana dan Joko Lianto Buliali $(2011)^{[7]}$, yang berjudul : "Perancangan dan Pembuatan Sistem Pencatatan Hasil Produksi dan Monitoring Kinerja Karyawan Produksi Pada PT BMI Surabaya”.
Tingginya tingkat subsidi pendapatan yang diberikan perusahaan menjadi latar belakang di lakukannya penelitian ini. Dimana setelah dilakukan analisa lebih lanjut ternyata diakibatkan oleh penurunan kinerja karyawan, yang akan berdampak pada penurunan output produksi, penambahan biaya produksi, tidak tercapainya rencana produksi yang telah ditetapkandan akhirnya menurunkan daya saing perusahaan dikancah internasional. Tujuan dari penelitian ini adalah untuk membuat sebuah sistem pencatatan hasil produksi dan monitoring kinerja karyawan berbasis teknologi informasi. Dengan sistem pencatatan yang baik maka akan mengurangi permasalahan tentang tingginya training cost (HRD), selisih hasil pencatatan hasil produksi dan kenyataan dilapangan (Produksi).

6) Penelitian yang dilakukan oleh Iwan Prasetyo (2013) ${ }^{[10]}$, STMIK Raharja. Penelitian yang telah dilakukan berjudul "Aplikasi Hasil Produksi Compound Berbasis Web Pada PT Gajah Tunggal Tbk". PT Gajah Tunggal Tbk yang bergerak dalam bidang pembuatan compound sudah terkomputerisasi namun masih menggunakan Ms.Excel, jadi ketika data dibutuhkan sering terjadi keterlambatan dalam penyajiannya. Ketika terjadi masalah sulit untuk mengecek laporan yang sudah lama. Saat ini semua kegiatan pembuatan laporan yang bertujuan untuk menghitung hasil efisiensi produksi masih menggunakan sistem yang masih sederhana yaitu menggunakan Microsoft Excel dimana setiap memasukkan data hasil produksi harus dilakukan satu-satu sehingga memakan waktu yang lama dan berpotensi adanya kesalahan memasukkan data dan ketika data dibutuhkan memerlukan waktu yang lama untuk menemukannya. 


\section{LANDASAN TEORI}

\section{Definisi Sistem}

Menurut Taufiq (2013:1) ${ }^{[15]}$, "Sistem yaitu kumpulan dari sub-sub sistem yang saling berhubungan dan bekerja sama". Masih menurut Taufiq $(2013: 5)^{[15]}$, "Tujuan sistem merupakan sasaran atau hasil yang diinginkan. Manusia, tumbuhan, hewan, organisasi, lembaga dan lain sebagainya pasti memiliki tujuan yang bermanfaat minimal bagi dia sendiri atau bagi lingkungannya".

Definisi Informasi

Menurut Hidayati dkk dalam Jurnal CCIT (2011:84) $)^{[5]}$, "Informasi adalah data yang diolah menjadi sebuah bentuk yang lebih berarti bagi penerimanya dan bermanfaat dalam mengambil suatu keputusan".

\section{Definisi Data}

Menurut Suprihadi dkk dalam Jurnal CCIT Vol. 6 No.3 (2013:310) ${ }^{[13]}$, "Data merupakan sekumpulan keterangan atau bukti mengenai sesuatu kenyataan yang masih mentah, masih berdiri sendiri, belum diorganisasikan dan belum diolah".

\section{Definisi Pengelolaan Data}

Menurut Yakub (2012:17) ${ }^{[16]}$, "Sistem informasi dalam organisasi biasanya terdiri atas berbagai metode pengelolaan data". Metode pengelolaan data terdiri dari: 1) Metode manual, merupakan pengelolaan data yang semua operasi datanya dilakukan dengan tangan dan bantuan alatalat. 2) Metode electromechanical, yang merupakan pengelolaan data dengan menggabungkan semua orang dan mesin. 3) Metode punched card equipment, merupakan pengelolaan data yang menggunakan semua alat yang disebut sistem warkat unit (unit record system). 4) Metode electronic computer, merupakan pengelolaan data dengan menggunakan komputerisasi.

\section{Definisi Website}

Menurut Yosef Murya (2012:3) ${ }^{[9]}$ "Website atau World Wide Web adalah Suatu layanan sajian informasi yang menggunakan konsep hyperlink (tautan) dengan menggunakan media untuk memudahkan surfer (sebutan para pemakai komputer yang melakukan browsing atau penelusuran informasi melalui internet)" didalam pencarian informasi.

\section{Definisi Laporan}

Menurut Rama dan Jones $(2008: 250)^{[14]}$, "Laporan adalah presentasi data yang telah terformat dan terorganisasi dengan baik". Didalam laporan juga terdapat jenis-jenisnya yang menurut Rama dan Jones $(2008: 251)^{[11]}$, Jenis-jenis laporan ini terbagi kedalam 2 (dua) hal, yaitu :

1) Laporan Ilmiah.

Laporan Ilmiah adalah laporan yang disusun melalui tahapan berdasarkan teori tertentu dan menggunakan metode ilmiah yang sudah disepakati.

2) Laporan Teknis.

Laporan tentang hal teknis penyelenggaraan kegiatan suatu badan atau instansi. Laporan teknis mengandung data obyektif tentang sesuatu data obyektif dalam laporan teknis itu juga mengandung sifat ilmiah, tetapi segi kepraktisannya lebih menonjol sehingga yang dimaksud dengan laporan teknis adalah suatu pemberitahuan tentang tanggung jawab yang dipercayakan dari si pelapor (perseorangan, tim, badan atau instansi) kepada si penerima laporan tentang teknis penyelenggaraan suatu kegiatan. Masih menurut Rama dan Jones (2008:253) ${ }^{[11]}$, Ciri-ciri laporan terdiri atas:

1) Ringkas; Dalam laporan yang ditulis hanya mengemukakan halhal pokok secara ringkas yang berhubungan dengan tugasnya sehingga penerima laporan segera mengetahui permasalahannya. 
2) Lengkap; Laporan dapat semakin sempurna jika dilengkapi dengan bibliografi atau sumber kepustakaan.

3) Logis; Laporan dianggap logis jika keterangan yang dikemukakannya dapat ditelusuri alasanalasannya yang masuk akal.

4) Sistematis; Laporan dianggap sistematik jika keterangan yamg tulisannya disusun dalam satuansatuan yang berurutan dan saling berhubungan.

Menurut Rama dan Jones $(2008: 296)^{[11]}$, Tipe - tipe laporan terdiri atas :

1) Simple event list, laporan yang menyediakan daftar kejadian sederhana selama satu periode waktu yang disusun menurut tanggal kejadian atau nomor transaksi tanpa mengelompokkan atau sub total.

2) Simple list, satu daftar kejadian atau daftar acuan sedeherhana.

3) Single entity report, laporan yang hanya menyediakan perincian mengenai satu entitas seperti barang, jasa, agen atau kejadian.

4) Status report, laporan yang menyediakan data ringkasan mengenai barang, jasa atau agen.

5) Summary report, laporan yang meringkas data kejadian untuk sekelompok record terkait selama periode tertentu.

6) Summary status report, laporan yang medaftar data acuan dan data ringkasan mengenai barang dan jasa atau agent.

\section{Definisi Produksi}

Menurut Rosnani Ginting (2007:5) ${ }^{[2]}$, "Produksi dalam pengertian sederhana adalah keseluruhan proses dan operasi yang dilakukan untuk menghasilkan produk atau jasa". Sistem produksi merupakan kumpulan dari sub sistem yang saling berinteraksi dengan tujuan mentransformasi input produksi menjadi output produksi. Input produksi ini dapat berupa bahan baku, mesin, tenaga kerja, modal dan informasi. Sedangkan output produksi merupakan produk yang dihasilkan berikut sampingannya seperti limbah, informasi dan sebagainya.

Menurut Vincent Gaspersz $(2005: 6)^{[3]}$, Sistem produksi memiliki beberapa karakteristik sebagai berikut :

1) Mempunyai komponen-komponen atau elemen-elemen yang saling berkaitan satu sama lain dan membentuk satu kesatuan yang utuh. Hal ini berkaitan dengan komponen struktural yang membangun sistem produksi itu.

2) Mempunyai tujuan yang mendasari keberadaannya yaitu menghasilkan produk (barang dan jasa) berkualitas yang dapat dijual dengan harga kompetitif dipasar.

3) Mempunyai aktivitas berupa proses transformasi nilai tambah input menjadi output secara efektif dan efisien.

4) Mempunyai mekanisme yang mengendalikan pengoperasiannya, berupa optimalisasi pengalokasian sumber-sumber daya.

Menurut Iswardono $(2004: 10)^{[6]}$, Fungsi produksi membatasi pencapaian profit maksimum karena keterbatasan teknologi dan pasar dimana hal ini akan mempengaruhi ongkos produksi, output yang dihasilkan dan harga jual output. Hubungan antara input dengan input, input dengan output dan output dengan output yang merupakan dan menjadi karakteristik dari fungsi produksi suatu perusahaan tergantung pada teknik produksi yang digunakan. Pada umumnya, semakin maju teknologi yang digunakan akan semakin meningkatkan output yang dapat 
diproduksikan dengan suatu jumlah input tertentu.

Menurut Pangestu Subagyo $(2000: 9)^{[14]}$, Untuk menghasilkan suatu produk dapat dilakukan melalui beberapa cara, metode dan teknik yang berbedabeda. Walaupun proses produksi sangat banyak, tetapi secara garis besar dapat dibedakan menjadi dua jenis yaitu :

1) Proses produksi terus-menerus (Continous process) Adalah suatu proses produksi dimana terdapat pola urutan yang pasti dan tidak berubahubah dalam pelaksanaan produksi yang dilakukan dari perusahaan yang bersangkutan sejak dari bahan baku sampai menjadi bahan jadi.

Kebaikan atau kelebihan proses produksi terus-menerus, yaitu: Dapat diperoleh tingkat biaya produksi per unit yang rendah, Biaya tenaga kerja rendah, karena jumlah tenaga kerja sedikit dan tidak memerlukan tenaga ahli, Biaya pemindahan bahan baku lebih rendah, karena jarak antara mesin yang satu dengan yang lain lebih pendek dan pemindahan tersebut digerakkan tenaga mesin.

Kekurangan atau kelemahan dari proses produksi terus-menerus, yaitu: Terdapat kesukaran dalam menghadapi perubahan produk yang diminta oleh konsumen atau pelanggan, Proses produksi mudah terhenti apabila terjadi kemacetan di suatu tempat atau tingkat proses, Terdapat kesalahan dalam menghadapi perubahan tingkat permintaan.

2) Proses produksi terputus-putus (Intermitten process) Adalah proses produksi dimana terdapat beberapa pola atau urutan pelaksanaan produksi dalam perusahaan yang bersangkutan sejak bahan baku sampai menjadi produk akhir.

Kebaikan atau kelebihan proses produksi terputus-putus, yaitu: Mempunyai fleksibelitas yang tinggi dalam menghadapi perubahan produk dengan variasi yang cukup besar, Mesin-mesin yang digunakan dalam proses bersifat umum, maka biasanya dapat diperoleh penghematan uang dalam investasi mesin-mesinnya, karena harga mesin-mesinnya lebih murah, Proses produksi tidak mudah terhenti akibat terjadinya kerusakan atau kemacetan di suatu tempat atau tingkat proses.

Yang menjadi kekurangan atau kelemahan proses produksi terputusputus yaitu: Scheduling dan routing untuk pengerjaan produk yang akan dihasilkan sangat sulit karena kombinasi urut-urutan pekerjaan yang banyak dalam memproduksi satu macam produk dan dibutuhkan scheduling dan routing yang banyak karena produksinya berbeda, tergantung pada pemesanannya, Dibutuhkan investasi yang sangat besar dalam persediaan bahan mentah dan bahan dalam proses, karena prosesnya terputus-putus dan produk yang dihasilkan tergantung pesanan serta Biaya tenaga kerja dan biaya pemindahan sangat tinggi, karena banyak menggunakan tenaga manusia dan tenaga yang dibutuhkan adalah tenaga ahli dalam pengerjaan produk tersebut.

\section{PEMBAHASAN}

PT Nikona Graha Tangerang bergerak di bidang Metal Komponen (Otomotif Park) PT Nikona Graha Tangerang mempunyai jenis barang yang berbeda- 
beda seperti Metal Stamping dan Karet, Bar Main Step K-15.A, Cutting Inner dan Outter, Packing Inner dan Outter dan Turret Inner dan Outter yang digunakan untuk kendaraan bermotor. PT Nikona Graha Tangerang memiliki tenaga kerja profesional yang sudah berpengalaman di bidangnya masing-masing.

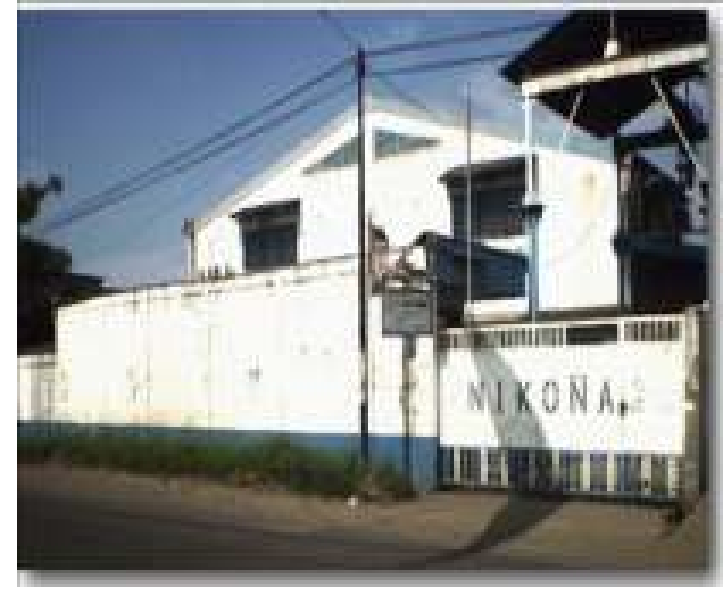

Gambar 1. Tampilan PT.Nikona Graha Tangerang

\section{Visi PT Nikona Graha Tangerang}

Menjadi perusahaan yang memproduksi metal komponen untuk kendaraan bermotor dan produk industri yang kompetitif, inofatif, berkualitas serta menjadi perusahaan yang terbaik di bidangnya.

\section{Misi PT Nikona Graha Tangerang}

1) Melakukan peningkatan dan perbaikan di bidang teknologi dan sumber daya manusia (SDM).
2) Memberikan nilai tambah kepada para pemegang saham.

3) Memproduksi dan menyediakan produk yang berkualitas.

4) Selalu mengutamakan kepuasan pelanggan.

\section{Prosedur Sistem Yang Berjalan}

Prosedur sistem yang saat ini sedang berjalan pada bagian produksi di PT Nikona Graha Tangerang yaitu :

1) Technical Staff mengatur formula mesin sebelum digunakan.

2) PPC membuat schedule produksi seperti Tanggal, No, Part Name, IP Product, Rencana Stock atau Forecast dan Rencana Produksi untuk Kepala Group.

3) Operator memproduksi barang, membuat laporan hasil produksi dan memberikan kepada administrator group.

4) Mechanic memperbaiki mesin yang ada masalah (kerusakan) dan mesin tidak berjalan sebagaimana mestinya.

5) Admin menginputkan laporan hasil produksi hasil produksi dan kemudian di print dan memberikannya kepada HRD.

6) Kepala Group dan HRD memeriksa laporan hasil produksi dan mengevaluasi hasil produksi.

Berikut dibawah ini adalah gambar ilustrasi pengelolaan data laporan hasil produksi pada PT. Nikona Graha Tangerang yang sedang berjalan saat ini : 


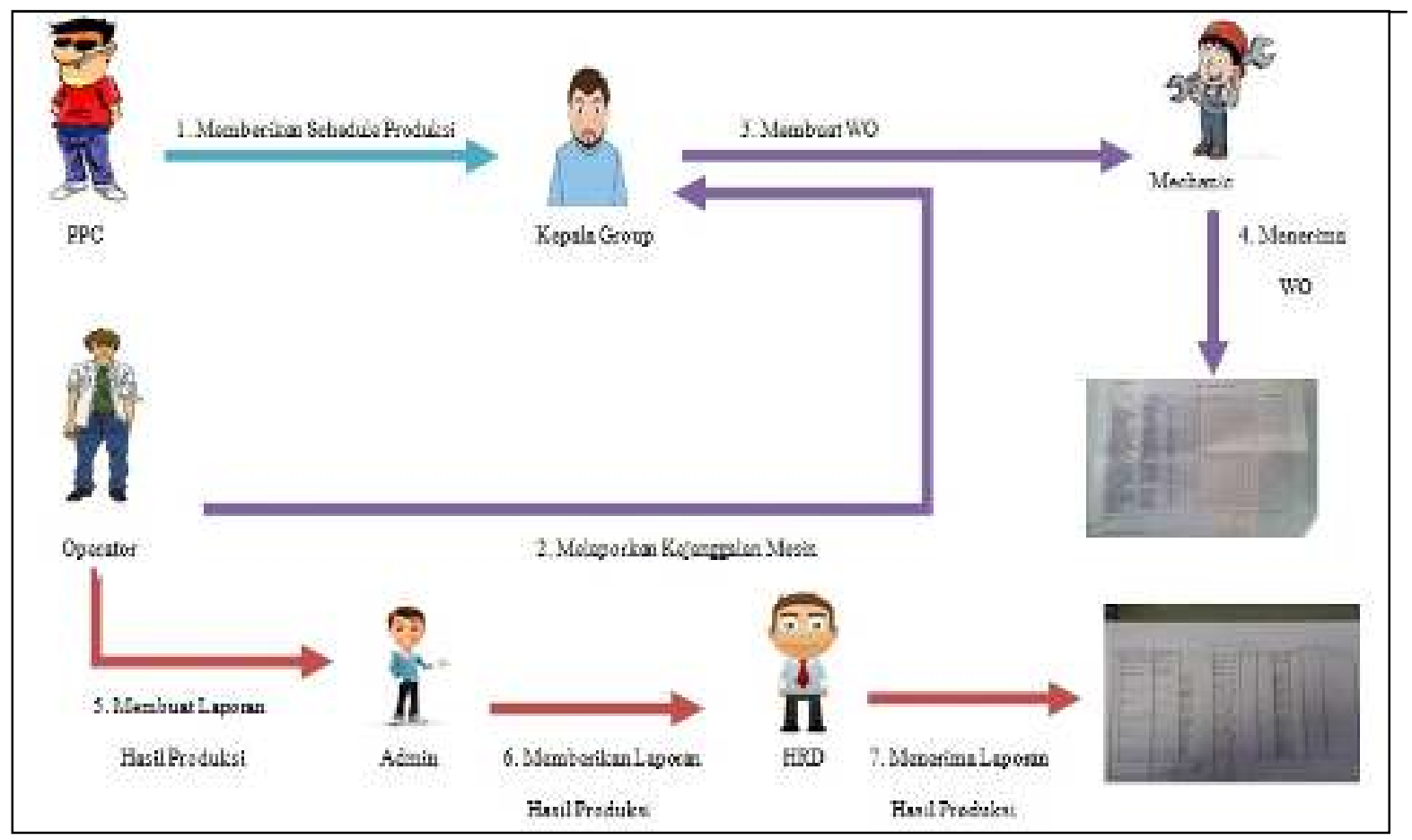

Gambar 2. Sistem pengelolaan data laporan hasil produksi yang berjalan pada PT.Nikona Graha Tangerang.

\section{Permasalahan yang dihadapi dan alternatif pemecahan masalah}

Berdasarkan penelitian yang dilakukan, diketahui permasalahan yang dihadapi pada PT Nikona Graha Tangerang yaitu sebagai berikut :

1) Kendala atau kelemahan prosedur sistem yang sedang berjalan saat ini adalah : pengelolaan laporan hasil produksi yang di lakukan masih bersifat pencatatan dengan menggunakan kertas.seperti laporan hasil produksi bertumpuk-tumpuk diatas meja sehingga laporan hasil produksi bisa hilang dan bisa tercampur dengan laporan hasil produksi yang sudah di input dan yang akan terkena dampaknya adalah admin.

2) Proses pencatatan yang masih dilakukan dengan menggunakan kertas, menyebabkan adanya kekurangan atau kesalahan yang dilakukan oleh petugas bagian produksi seperti, kehilangan form laporan hasil produksi, serta terjadinya laporan hasil produksi tercampur dengan laporan hasil produksi yang sudah di input, karena data yang tersimpan kurang tersusun rapih sehingga laporan hasil produksi bisa tercampur dengan laporan hasil produksi yang lainnya.

3) Seluruh informasi mengenai laporan hasil produksi, setiap hari dikumpulkan dimana semua datadata yang ada akan diajukan sebagai laporan hasil produksi bulanan kepada bagian produksi.

Setelah mengamati dan meneliti dari beberapa permasalahan yang terjadi pada sistem yang berjalan, terdapat beberapa alternatif pemecahan dari permasalahan yang dihadapi, antara lain :

1) Membuat aplikasi pengelolaan laporan hasil produksi yang mudah dioperasikan dengan cepat.

2) Membuat aplikasi yang mudah di akses oleh bagian produksi.

3) Mempunyai tempat penyimpanan data yang aman sehingga data-data yang ada tidak mudah hilang dan juga penyimpanan data menjadi lebih terintegrasi. 


\section{IMPLEMENTASI}

Tampilan halaman login merupakan sebuah halaman untuk memasukkan identitas seperti username dan password yang benar. Fungsi utama halaman login adalah untuk melidungi sistem.

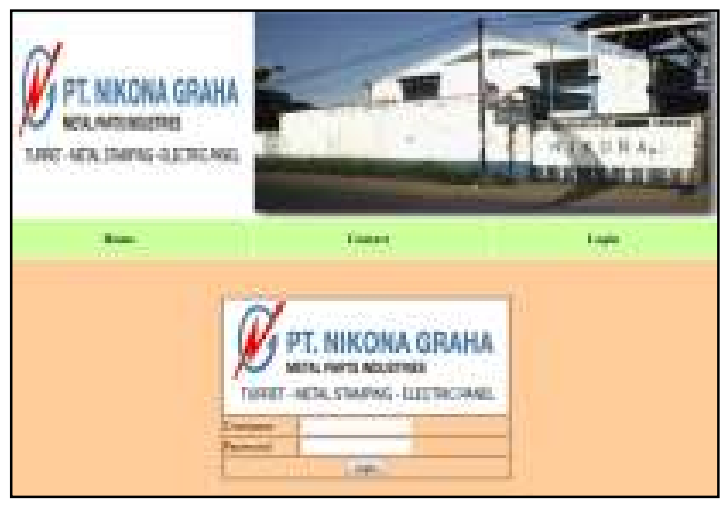

Gambar 3. Tampilan Halaman Login

Tampilan halaman home merupakan halaman yang berisi menu-menu dari sebuah web. Menu-menu home ini terdiri dari menu group, menu operator, menu shift kerja, menu schedule produksi, menu laporan hasil produksi, menu rekap laporan bulanan dan menu logout

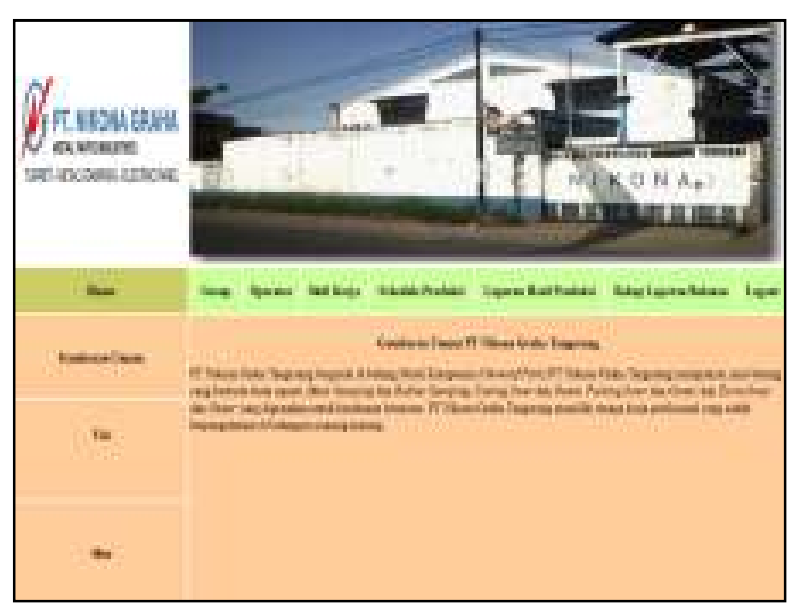

Gambar 4. Tampilan Halaman Home

Tampilan halaman group ini berisi tabel tampil kepala group untuk melihat nama kepala group, NIK, nomor KPA, tanggal masuk, pendidikan akhir, status dan shift kerja.

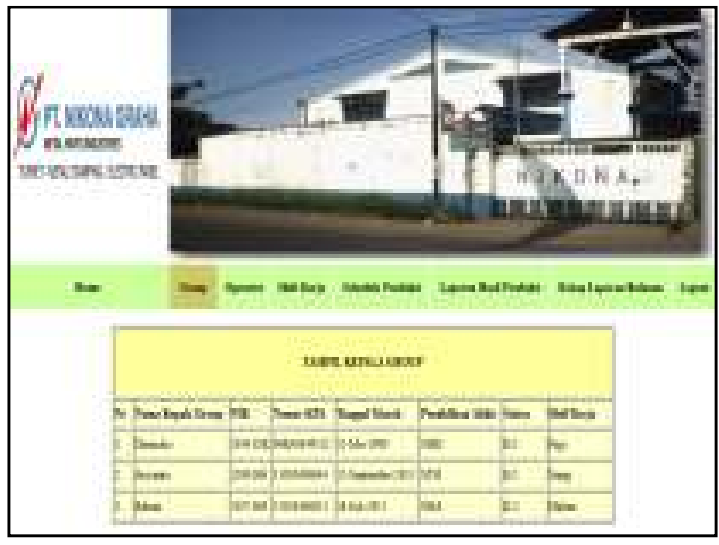

Gambar 5. Tampilan Halaman Group

Tampilan halaman operator ini berisi tabel tampil operator untuk melihat nama operator, status, tanggal masuk, habis masa HL (Harian Lepas), shift kerja, nama kepala group dan mesin.

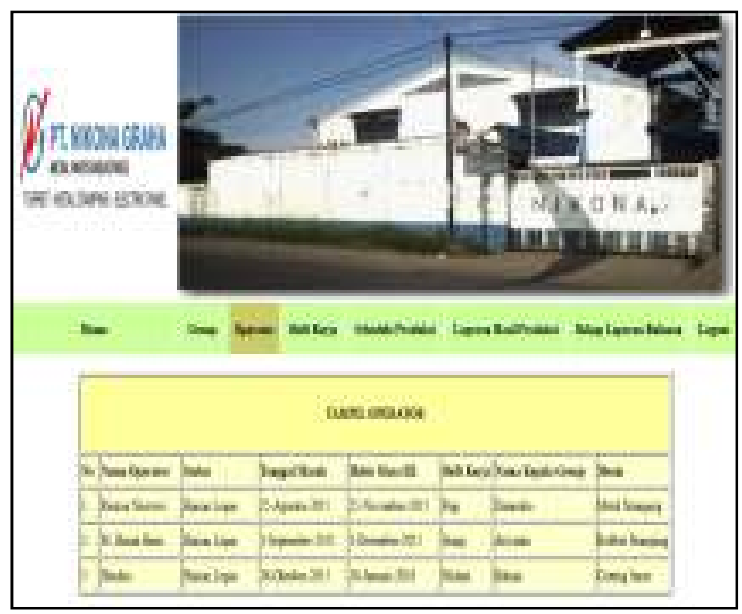

Gambar 6. Tampilan Halaman Operator

Tampilan halaman shift kerja ini berisi tabel tampil shift kerja untuk melihat shift kerja, masuk, pulang dan keterangan.

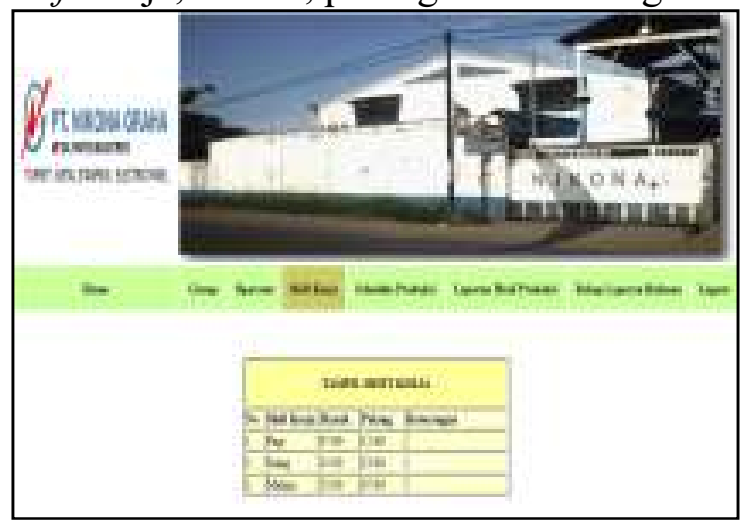

Gambar 7. Tampilan Halaman Shift Kerja 
Tampilan halaman schedule produksi ini berisi tabel tampil schedule produksi untuk melihat tanggal, part name, IP product, rencana stock/forecast dan rencana produksi.

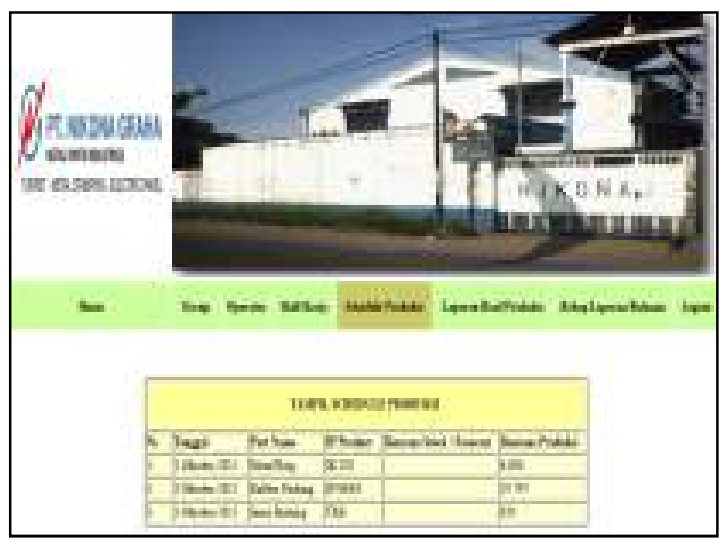

Gambar 8. Tampilan Halaman Schedule produksi

Tampilan halaman Laporan metal stamping ini berisi tabel tampil metal stamping untuk melihat tanggal, nama kepala group, nama operator, shift kerja dan jumlah.

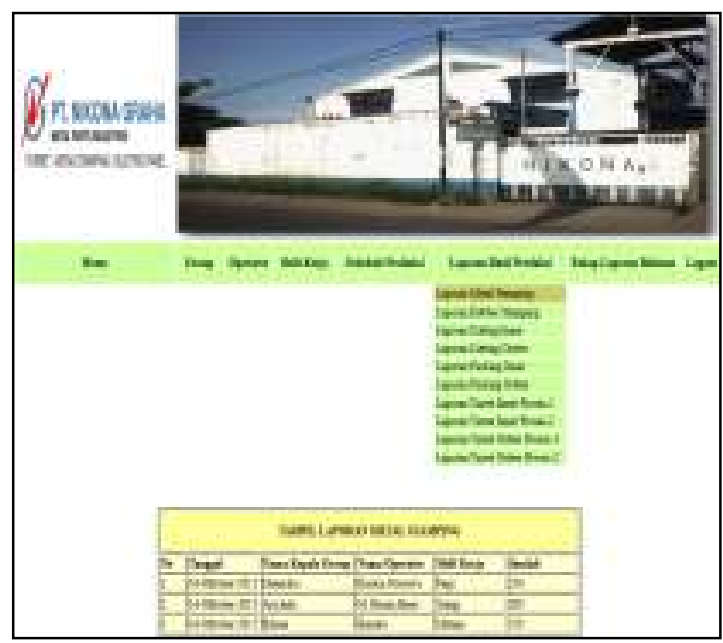

\section{Gambar 9. Tampilan Halaman Laporan Metal Stamping}

Tampilan halaman Laporan rubber stamping ini berisi tabel tampil rubber stamping untuk melihat tanggal, nama kepala group, nama operator, shift kerja dan jumlah.

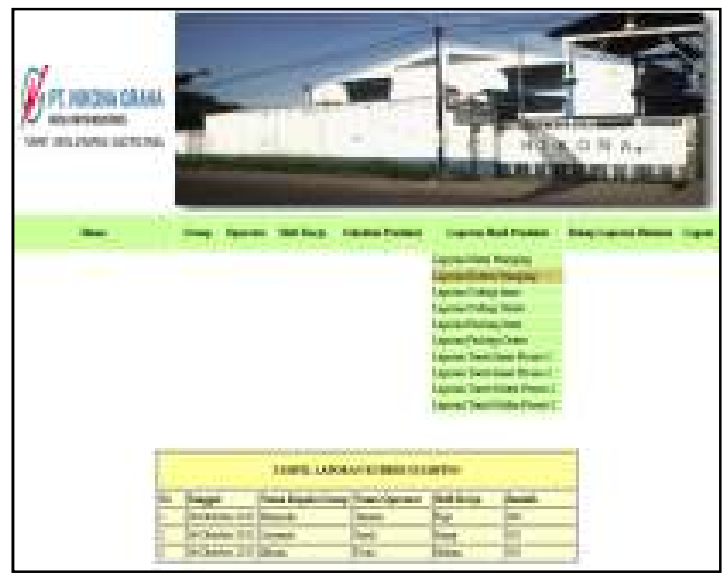

Gambar 10. Tampilan Halaman Laporan Rubber Stamping

Tampilan halaman Laporan cutting inner ini berisi tabel tampil cutting inner untuk melihat tanggal, nama kepala group, nama operator, shift kerja, reject dan jumlah.

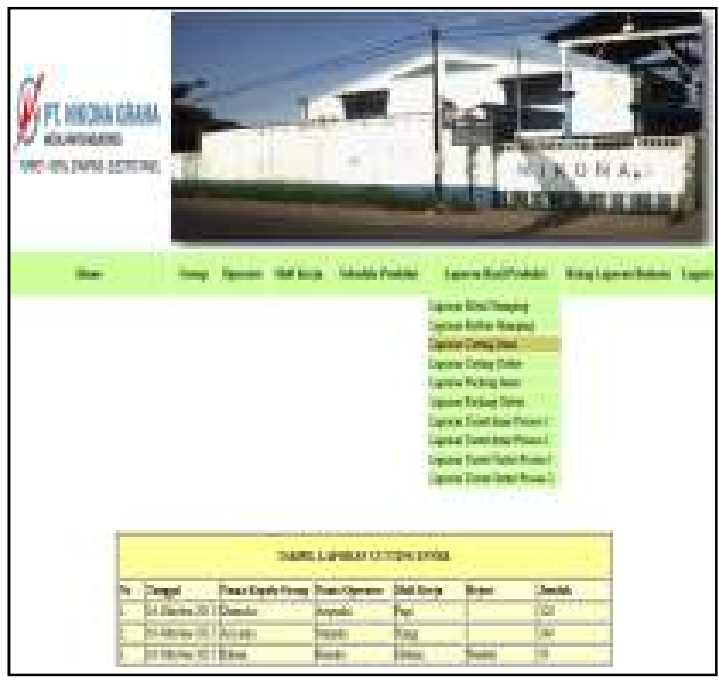

Gambar 11. Tampilan Halaman Laporan Cutting Inner

Tampilan halaman Laporan cutting outter ini berisi tabel tampil cutting outter untuk melihat tanggal, nama kepala group, nama operator, shift kerja, reject dan jumlah. 


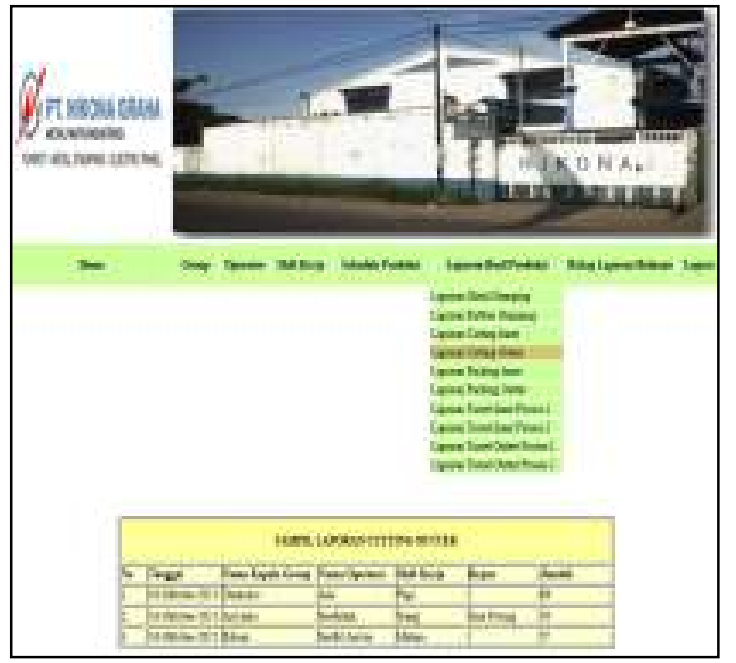

Gambar 12. Tampilan Halaman Laporan Cutting Outer

Tampilan halaman Laporan packing inner ini berisi tabel tampil packing inner untuk melihat tanggal, nama kepala group, nama operator, shift kerja, reject dan jumlah.

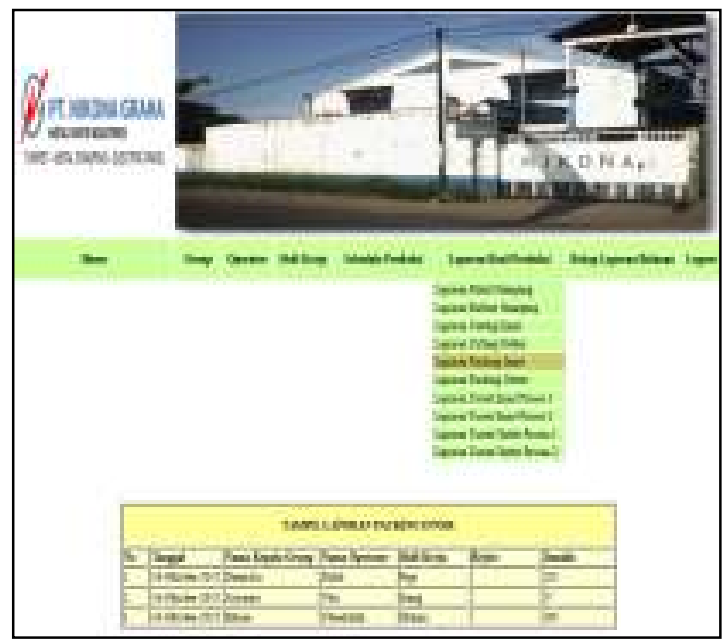

\section{Gambar 13. Tampilan Halaman Laporan Packing Inner}

Tampilan halaman Laporan packing outter ini berisi tabel tampil packing outter untuk melihat tanggal, nama kepala group, nama operator, shift kerja, reject dan jumlah.

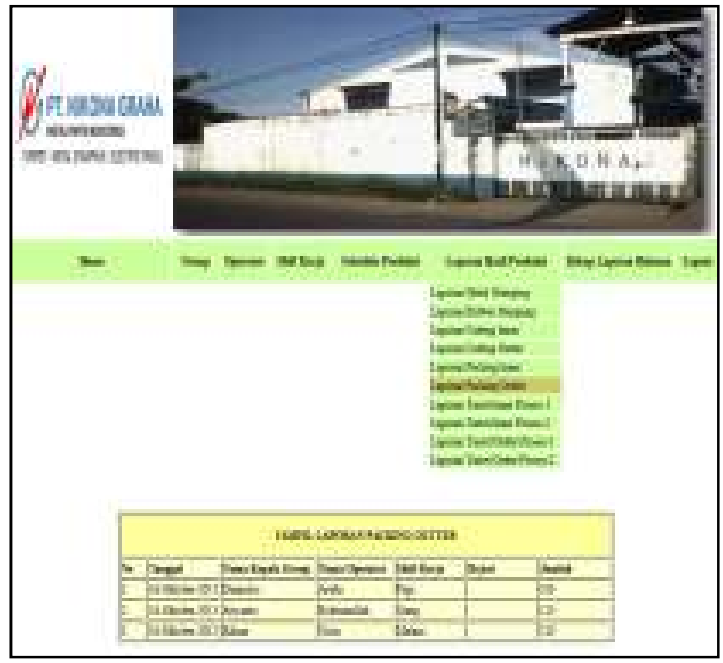

Gambar 14. Tampilan Halaman Laporan Packing Outer

Tampilan halaman Laporan turret inner proses-1 ini berisi tabel tampil turret inner proses-1 untuk melihat tanggal, nama kepala group, nama operator, shift kerja, reject dan jumlah.

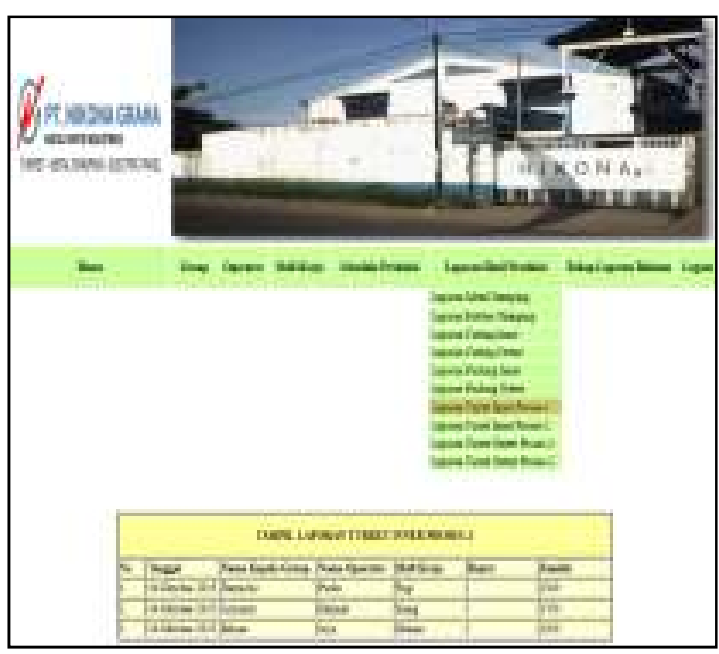

Gambar 15. Tampilan Halaman Laporan Turret Inner Proses-1

Tampilan halaman Laporan turret inner proses-2 ini berisi tabel tampil turret inner proses-2 untuk melihat tanggal, nama kepala group, nama operator, shift kerja, reject dan jumlah. 


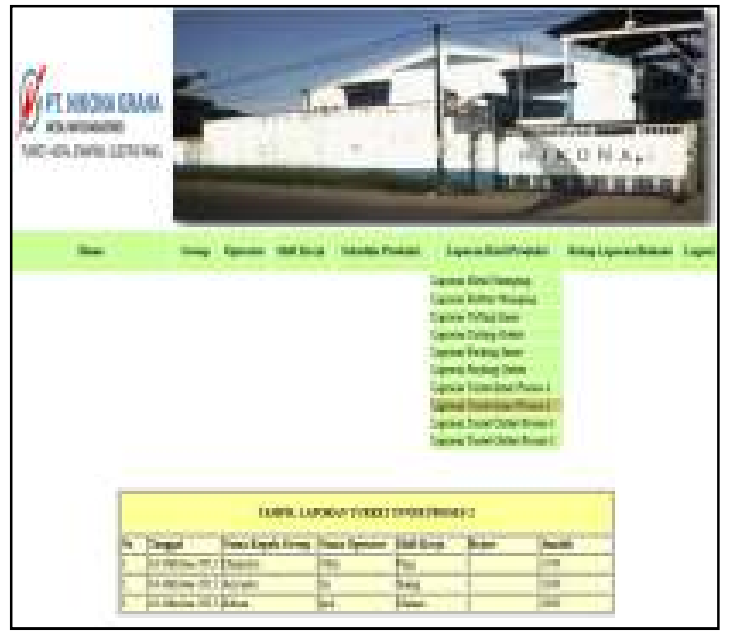

Gambar 16. Tampilan Halaman Laporan Turret Inner Proses-2

Tampilan halaman Laporan turret outter proses-1 ini berisi tabel tampil turret outter proses-1 untuk melihat tanggal, nama kepala group, nama operator, shift kerja, reject dan jumlah.

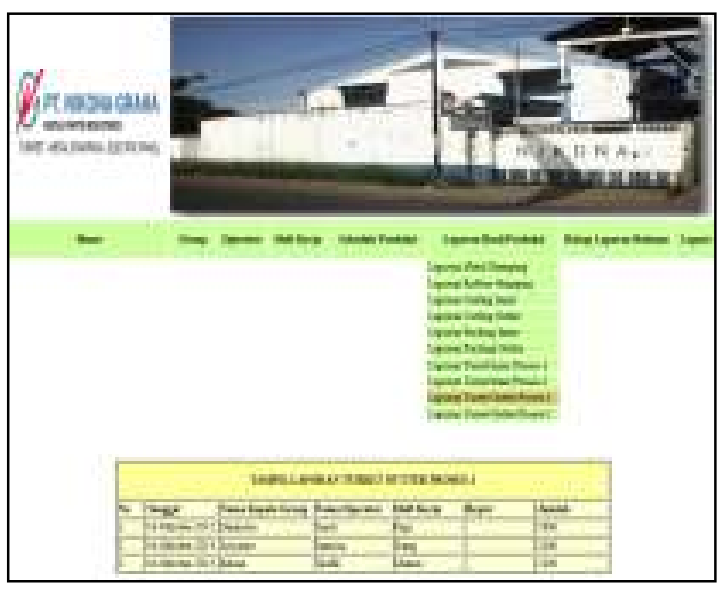

Gambar 17. Tampilan Halaman Laporan Turret Outer Proses-1

Tampilan halaman Laporan turret outter proses-2 ini berisi tabel tampil turret outter proses-2 untuk melihat tanggal, nama kepala group, nama operator, shift kerja, reject dan jumlah.

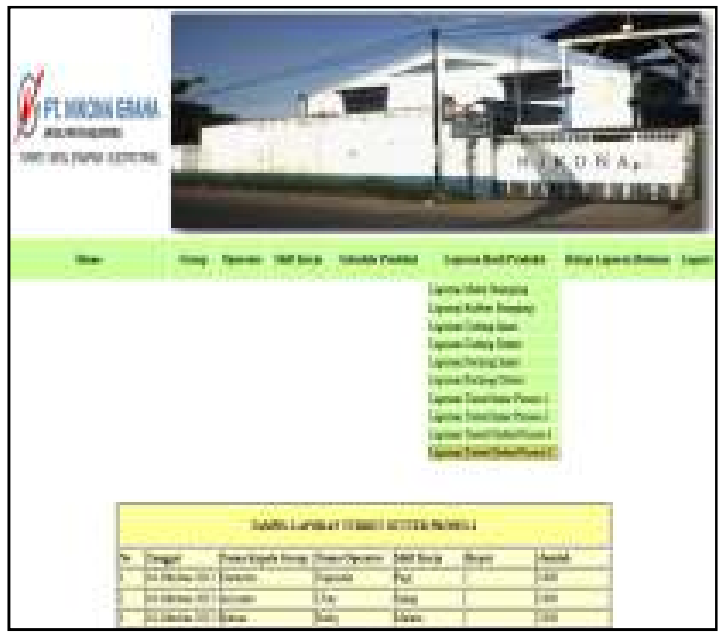

Gambar 18. Tampilan Halaman Laporan Turret Outer Proses-2

Tampilan halaman rekap laporan bulanan ini berisi tabel tampil rekap laporan bulanan untuk melihat tanggal, proses, nama kepala group, hasil produksi, rijection rate, keterangan dan total hasil produksi.

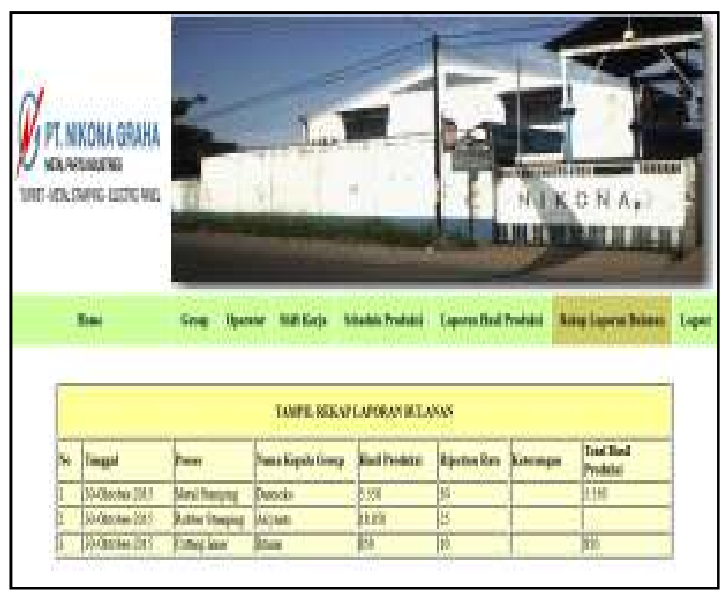

Gambar 19. Tampilan Halaman Rekap Laporan Bulanan

\section{KESIMPULAN}

Berdasarkan pada uraian-uraian yang telah dijelaskan, maka dapat disimpulkan beberapa hal yang tentunya sesuai dengan data-data yang sebenarnya sebagai berikut 
1) Sistem yang sedang berjalan pada PT Nikona Graha Tangerang pada saat ini terutama dalam hal pengelolaan data laporan hasil produksi masih manual yaitu proses pencatatan laporan hasil produksi yang dilakukan oleh bagian produksi masih menggunakan kertas dan tidak bisa melakukan penginputan laporan hasil produksi di hari yang sama karena laporan hasil produksi dicatat di form hasil produksi menggunakan kertas sehingga membutuhkan waktu yang lama dalam mengolah data.

2) Sistem yang sedang berjalan pada PT Nikona Graha Tangerang pada saat ini terutama dalam hal pengelolaan data laporan hasil produksi penyimpanan data-datanya masih kurang aman dan kurang tertata dengan baik karena tidak ada tempat penyimpanan data yang baik seperti kertas laporan hasil produksi bertumpuk-tumpuk diatas meja sehingga laporan hasil produksi bisa hilang dan tercampur dengan laporan hasil produksi yang sudah di input.

\section{DAFTAR PUSTAKA}

[1] Busyrol,Hana. 2010. "Aplikasi Pengolahan dan Pelaporan Data Hasil Produksi Kertas NCR di PT. Pura Barutama Unit Coating Kudus". Universitas Negeri Semarang.

[2] Ginting,Rosnani. 2007. "Sistem Produksi”. Yogyakarta: Graha Ilmu.

[3] Gaspersz,Vincent. 2005. "Total Quality Management". Jakarta: Gramedia Pustaka Utama.

[4] Haryono,Riwan Tri. Iriani,Siska. 2013. "Perancangan Sistem Informasi Pengolahan Data Produksi Dan Penjualan Pada Pabrik Penggergajian Batu CV Bumi Indah Persada".
[5] Hidayati, Rahardja Untung, Mia Novalia. 2011. "Peningkatan Kerja Distributed Database Melalui Metode DMQ Base Level". Jurnal CCIT Vol.4 No.3 - Mei 2011 ISSN: 1978-8282 STMIK Raharja.

[6] Iswardono. 2004. "Teori Ekonomi Mikro (Micro Economics Theory)" Yogyakarta: UPP AMP YKPN.

[7] Khristiana,Femin dan Buliali,Joko Lianto. 2011. "Perancangan dan Pembuatan Sistem Pencatatan Hasil Produksi dan Monitoring Kinerja Karyawan Produksi Pada PT BMI". Surabaya.

[8] Legowo,Nilo. 2012. "Perancangan Aplikasi Monitoring Produksi Pada Perusahaan Yang Memproduksi Acrylic". Universitas Binus.

[9] Murya,Yosef. 2012."PHP Menyelesaikan Website 30 Juta". Yogyakarta: Jasakom.

[10] Prasetyo,Iwan. 2013. “Aplikasi Hasil Produksi Compound Berbasis Web Pada PT Gajah Tunggal Tbk". STMIK Raharja.

[11] Rama,Dasaratha V, dan Jones, Frederick L. 2008. "Sistem Informasi Akuntansi. Buku Satu. (Alih Bahasa M. Slamet Wibowo)". Jakarta: Salemba Empat.

[12] Soedjianto, Felicia. Oktavia,Tanti. Anggawinata, James Arthur. 2006. Perancangan dan Pembuatan "Sistem Perencanaan Produksi (Studi Kasus Pada PT Vonita Garment)". Universitas Kristen Petra.

[13] Suprihadi, Rini Kartika Hudiono, Lina Sinatra Wijaya. 2013. "Rancang Bangun Sistem Jejaring Klaster Berbasis Web 
Menggunakan Metode Model View Controller". Vol.6 No.3 - Mei 2013 ISSN: 1978-8282 STMIK Raharja.

[14] Subagyo, Pangestu. 2000. "Manajemen Operasi".Yogyakarta: BPFE.

[15] Taufiq, Rohmat. 2013. "Sistem Informasi Manajemen”. Yogyakarta: Graha Ilmu.

[16] Yakub.2012.'Penghantar Sistem Informasi”.Yogyakarta:Graha Ilmu. 